\title{
OWNERSHIP STRUCTURE AND FINANCIAL REPORTING QUALITY IN LISTED NON-FINANCIAL FIRMS IN NIGERIA
}

\author{
Dr. Junaidu Muhammad Kurawa \\ Professor \\ Department of Accounting \\ Bayero University, Kano, Nigeria \\ E-mail: mmjnkurawa@gmail.com \\ (D)https://orcid.org/0000-0002-8919-5339 \\ Ismail Alhassan \\ Department of Accounting \\ School of Business Education, Federal College of Education \\ (Technical), Gombe, Gombe State, Nigeria \\ E-mail: alhassan1412@gmail.com \\ https://orcid.org/0000-0003-0038-3841 \\ K. M. Anwarul Islam \\ Associate Professor \\ Department of Business Administration \\ The Millennium University, Dhaka, Bangladesh \\ E-mail: anwarul@themillenniumuniversity.edu.bd \\ (iD) https://orcid.org/0000-0002-5305-6724 \\ Dr. Md. Shariful Haque \\ Associate Professor \\ Department of Economics \& Banking \\ International Islamic University Chittagong, Bangladesh \\ E-mail: sharif@iiuc.ac.bd \\ https://orcid.org/0000-0002-2692-3634
}

Received: September 13, 2021 Accepted: November 14, 2021 Online Published: December 31, 2021

DOI: 10.46281/ijafr.v9i1.1547

URL: https://doi.org/10.46281/ijafr.v9i1.1547

\begin{abstract}
The objective of this study is to appraise the effect of the ownership structure on the quality of financial reporting in Nigeria. The study used data from 41 non-financial firms listed on the Nigerian Stock Exchange (NSE) for the 2011 to 2019 period. The Generalised Method of Moments (GMM) technique was adopted for the study which is vigorous to the threat of heteroskedasticity and endogeneity. The study findings revealed that institutional and foreign ownership has a significant negative relationship with earnings management, thereby, improving the reporting quality. However, the results show that managerial ownership has an insignificant negative relationship with earnings management. The finding
\end{abstract}


of this study is also robust in scope concerning the issue of unobserved heterogeneity which prior studies have failed to address. Thus, future corporate governance reforms should recognize and sustain these efforts. The study recommends that Firms should expand their institutional and foreign ownership by providing sufficient shares to them. This is important because they frequently deploy their professionalism and wealth of experience to the firms towards meeting corporate goals and agitation of good reporting practice. On the other hand, Firms should ensure that the shareholding of the insider managers is not too high in such a way that the proportion of their shareholding should be minimal. Their shares should not exceed $10 \%$ of the total shareholding in the company as it was found to be among the variables that reduce firms' performance.

Keywords: Earnings Management, Financial Reporting Quality, Ownership Structure.

\section{JEL Classification Codes: G32.}

\section{INTRODUCTION}

The quality of financial reporting is one of the major concerns among the stakeholders of quoted companies. This is because financial reporting has long been a critical technique of conveying to outsiders the results of activities and events that have occurred within the business. It enables them to use such data to examine the economic performance and financial positions of firms, as well as to drive economic decisions. As a result, every user of financial information expects that the data will assist him in assessing the reporting entity's health and making sensible financial decisions. However, recent events, particularly a series of corporate scandals involving Enron, Worldcom, Parmalat, and several Nigerian firms, including Cadbury Nigeria Plc in 2006, Afribank Nigeria Plc in 2009, and Intercontinental Bank Plc in 2009 , have cast serious doubt on the quality of financial reports circulating in a corporate environment and their ability to meet the expectations and needs of users (Elyasiani, Wen, \& Zhang, 2017). Various studies on various aspects of financial reporting quality have been done by researchers. Convergence of accounting standards, harmonization of accounting standards, economic crises, increased disclosure requirements, and other factors have resulted in an over-concentration on financial reporting. In addition, the rise in accounting scandals around the world in the early twenty-first century has shown flaws in financial reporting quality (FRQ). The value of accounting reporting is determined by the quality of financial reporting. A clear and complete definition of FRQ is in high demand all across the world. Highquality financial reporting is vital for influencing users' investment decisions and improving market efficiency.

As a result of their knowledge, the inclusion of IO in the Code of Corporate Governance (CCG) has continued to change the capital market, reduce information asymmetry, and control management (Bamahros \& Wan-Hussin, 2016). Furthermore, IOs can act as a liaison between the AC and external auditors to ensure that both comply with regulations by producing high-quality, timely financial reporting through the proper application of relevant accounting standards, such as the International Financial Reporting Standards (IFRS). The institutional monitoring goal is to improve the firm's strength and increase future stock returns (Gugong, Arugu, \& Dandago, 2014). Furthermore, dedicated IOs wield a great deal of control on firm management, resulting in a variety of abilities and attitudes for monitoring investees. Momentary IOs, on the other hand, with a short-term performance focus and conduct more akin to traders than owners, result in earnings disappointment and large-scale institutional selling, offering fertile ground for opportunistic managerial behavior.

Long-term IOs own significant amounts of equity in both the financial and non-financial sectors in Nigeria, including pension funds, mutual funds, endowment funds, and sovereign wealth funds. As of December 2015, IOs accounted for around 54\% of domestic commerce. Dedicated IOs, in addition to 
superior trading, have voting power and investing abilities to shape managers' opportunistic behavior, and are thus required to play a monitoring function by ensuring compliance with CG regulations.

Furthermore, management stock ownership can improve organizational performance by better aligning monetary incentives between managers and other equity owners (Okafor, Ugochukwu, \& Chijindu, 2016). Managers with more stock ownership are more capable of resisting a market takeover challenge for corporate control, which can improve corporate performance. As a result, takeover premiums will be higher for raiders in this market (Kim, 2010). Managers with a stake in the company, on the other hand, maybe more active and endeavor to preserve the company's interests at all costs. It's because they should believe and feel that the organization's failure is a reflection of their own failure, which could result in the loss of their equity holding. Managers who own stock in a company, on the other hand, will endeavor to increase the company's performance in order to obtain a high return in the form of dividends and bonus issues.

Similarly, the rapid expansion in foreign direct investment in emerging capital markets makes foreign investors large institutional investors with a significant influence in corporate governance. Various previous studies on foreign investors and FRQ in emerging nations show that foreign participation has a major advantage over individual shareholders or family ownership (Indrarini, Chandrarin, \& Subiyantoro, 2019). Due to rising foreign investor shareholdings, the importance of foreign investors as external monitors of corporate governance activities is continuously expanding, notably in most emerging nations. Despite the importance of foreign investors in emerging markets, empirical research on the relationship between foreign investors and earnings quality is scarce. However, in the context of the transitory hypothesis, foreign investors are only short-term investors, and as a result, they have little influence over the management of the firm (Khafid \& Arief, 2017). As a result, dedicated institutional shareholders, such as pension funds, have a greater impact on enhancing financial reporting quality and, as a result, minimizing earnings management. Domestic investors, according to Sepasi, Kazempour, and Mansourlakoraj (2016), are less sophisticated and adopt the opposite viewpoint in the capital market as more influential foreign investors. They assert that foreign investors tend to pursue impetus strategy, unlike domestic investors that seem to be submissive. The rest of the paper covered the literature review, methodology, results in interpretations, conclusion, and recommendations.

\section{Financial Reporting Concept}

\section{LITERATURE REVIEW}

Financial reporting is the precise manner in which a report displays information about a business activity as it pertains to predicted cash flows, with the goal of informing shareholders about a company's operations (Uche, Adegbite, \& Jones, 2016). FRQ is defined by Yaghoobi and Khansalar (2016) as the degree to which financial statements give information that is relevant and reliable regarding an enterprise's financial status and performance. However, Amin, Dutta, Saadi, and Vora (2015) gave a widely accepted definition, stating that financial reporting quality is defined as comprehensive and explicit information designed to help users. The objective of financial reporting, according to the International Accounting Standard Board (IASB), is to provide financial information about the reporting entity that is useful to present to prospective equity investors, lenders, and other creditors in making decisions in their capacity as capital providers. Financial reporting quality will undoubtedly improve if the aims and qualitative features of financial reporting information are met.

\section{Qualitative Attributes of Financial Reporting}

The Financial Accounting Standard Board (FASB) and the International Accounting Standards Board (IASB) stipulated that there are agreed-upon characteristics of high-quality financial reporting in their 
Conceptual Framework for Financial Reporting. Relevance, reliability, faithful representation, understandability, comparability, verifiability, and timeliness are some of the qualitative properties of FRQ. They are classified into two categories: core qualitative elements and qualitative traits that improve quality. Each of these phrases has a theoretical explanation that highlights their relevance as qualitative features and also identifies which qualities are regarded basic in different frameworks.

\section{Measuring Financial Reporting Quality}

Various measurement models have been used in prior researches for the assessment of FRQ. Some of these include (i) accrual models (Jones, 1991; Dechow, Sloan, \& Sweeney, 1995); (ii) value relevance model (Wahyu, Budiyanto, \& Nur, 2016); (iii) specific elements in annual reports (iv) qualitative characteristics model (Ongore, K'Obonyo, \& Ogutu, 2011). However, the most widely used models among the scholars are the accrual models which are considered in this study.

\section{Accrual Model}

The level of earnings management is used as a proxy for the quality of financial reporting in this model. It assesses the extent to which earnings are managed under current laws and regulations. The approach implies that managers manage earnings through discretionary accruals or accruals over which the management has some control (Arowolo \& Che-Ahmad, 2017). This model is predicated on the notion that a company's earnings are the most important item in its financial statements. As a result, most analysts consider this when evaluating a company's current and future prospects. EM is thought to have a negative impact on financial reporting quality by lowering its decision-making utility (Mamman, Kurfi, Audi, Amos, \& Ahmad, 2016). There are a variety of methods for detecting earnings management, but accrualbased models, particularly discretionary accrual, are the most prevalent (Khafid \& Arief, 2017). The key advantages of employing discretionary accruals to monitor earnings management, according to proponents of this paradigm, are the relative ease of data collection and measurement. Furthermore, regression models can be used to investigate the impact of corporate factors on the extent of earnings management (Brooks, Chen, \& Zeng, 2018). However, the model's fundamental flaw is its inability to distinguish between discretionary and non-discretionary accruals (Dou, Hope, Thomas, \& Zou, 2018). Furthermore, the model only provides a proximate measure of FRQ.

EM is widely used in the measurement of FRQ. Managers typically use it to make changes to figures in the financial statement (Alsmady, 2018). They claim that EM occurs when managers use subjective judgment in financial reporting and transaction structuring to alter financial reports in order to mislead some stakeholders about the company's underlying economic performance or to influence contractual outcomes that are based on reported accounting practices. Earnings management, according to Lakhal et al. (2015), happens as a result of the Generally Accepted Accounting Principles' loopholes and flexibility of accounting decisions (GAAP). Managers can use these loopholes to select reporting techniques that allow them to make estimates and assumptions that suit their corporate environment or maximize their wealth. Discretionary accruals model as a measurement tool for FRQ becomes desired in a situation where managers utilize subjective judgments in financial reporting to alter financial reports, consequently negatively compromising the quality of financial reporting (Al-Jaifi, Al-Rassas, \& AlQadasi, 2019). Major strands in the existing literature on FRQ have been proxied by EM, which studies managers' use of discretionary accruals to move reported revenue across fiscal periods, corroborating the previous assumption. Separating the non-discretionary accruals from the total accruals yields discretionary accruals. To that purpose, the modified Jones (1991) model, which has been endorsed by some accounting professionals, was employed in this study. 


\section{Institutional Ownership and Financial Reporting Quality}

In sophisticated jurisdictions around the world, institutional investors play a significant role in financial markets. In recent years, investing in IO funds has become more popular. This type of investment appeals to both private and institutional investors because it provides a level of diversification that is difficult to reproduce through indirect investing. Because some securities offerings are only available to institutional investors, it also gives individual investors broad market access (Khafid \& Arief, 2017). They are costeffective because they profit from economies of scale in terms of dealing, custody, and transfer of securities because they operate on a larger scale. They also address liquidity issues, which are common in markets with concentrated ownership.

The question of whether investor activism is good or bad for a firm has been debated for a long time. Some argue that investors should not be given such a high priority in a firm's corporate governance because they lack the necessary skills to monitor the organization. They also believe that this would divert their attention away from their core business, but others believe that institutional investors must play a key role in enhancing corporate governance processes (Affan, Rosidi, \& Purwanti, 2017). According to Bamahros and Wan-Hussin (2015), there are some factors to examine before an institutional investor decides to actively participate in a company's operations. They must undertake a cost-benefit analysis to determine whether the expense of getting information to actively participate in the company's activities and to monitor the company's affairs is less than the advantages they would receive as a consequence of such monitoring. They would be actively involved in the business of the company if this is the case; otherwise, they would not. The following hypothesis has been proposed:

Ho1 Institutional ownership has no significant relationship with EM practice by listed firms in Nigeria.

\section{Managerial Ownership and Financial Reporting Quality}

On-board or managerial ownership is another aspect of governance that influences the board monitoring activity of managers. This is the total number of shares owned by Chief Executive Officers (CEOs), which includes restricted shares but excludes stock options, and is expressed as a percentage of the company's total outstanding shares (Kim, 2010). Managerial ownership, according to Saifullah, Mohammed, and Usman (2015), is the percentage of shares held by officers and directors. Managerial ownership can also be defined as a position in which a manager has the authority to make decisions about the company's strategies and policies (Adebiyi \& Olowookere, 2016). Managerial ownership grows as a result of the increase in managerial ownership, which encourages managers to accept responsibility for wealth and, as a result, aligns the interests of management and shareholders. Managerial incentives to consume advantages and expropriate shareholder wealth are reduced as a result.

In the literature, there are two contrasting perspectives on managerial ownership and FRQ. Moral hazard and knowledge asymmetry between internal and external investors are common outcomes of huge ownership. Management may be more motivated to distort financial statements. According to Alsmady (2018), monitoring is more difficult if the company is owned by managers (Dou et al., 2018). Managers with lesser stock ownership, on the other hand, are more likely to alter accounting statistics in order to overcome restrictions imposed on accounting-based pay contracts, according to agency theory. Furthermore, an outside board with a limited share of the company's equity cannot properly monitor the managers. The interest alignment theory, on the other hand, suggests that board and management ownership can successfully encourage manager performance and provide incentives for an independent board to supervise management. The following hypothesis has been proposed:

Ho2 Managerial ownership has no significant relationship with EM practice by listed firms in Nigeria. 


\section{Foreign Ownership and Financial Reporting Quality}

The percentage of a company's share capital held by foreigners is known as foreign ownership. As a large institutional investor, I have two opposing perspectives on foreign investors: active surveillance and transient hypothesis. Foreign investors, according to the active monitoring hypothesis, play a critical role in monitoring management in order to safeguard their interests and overcome the information asymmetry problem. Foreign investors, especially outside block shareholders in emerging countries, play a crucial role in supervising management, according to (Bricker \& Markarian, 2015). This is because foreign investors have collective bravery to safeguard their investment. According to Dou et al. (2018), foreign institutional investors' shareholdings have a positive association with firm value, indicating that foreign institutional investors have the power and bravery to oversee firms' operations, hence improving the monitoring system. As significant institutional investors, foreign shareholders play an important role in monitoring. External oversight by major institutional investors, such as foreign investors, might limit management's discretionary decisions to release financial information, lowering earnings management (Affan et al., 2017). Foreign investors, likewise, may be clever traders looking to invest in specific companies, such as huge corporations that perform well and give substantial dividends. Foreign investors in Japanese firms hold shares in large manufacturing companies with good business performance, lower leverage, and lower unsystematic risk, according to Elyasiani et al. (2017), implying that foreign investors are more knowledgeable and informed about well-performing firms than domestic investors. The following hypothesis has been proposed:

Ho3 Foreign ownership has no significant relationship with EM practice by listed firms in Nigeria.

\section{Firm's Growth}

The existing literature on the association between firm expansion and profits quality shows varied results. According to Okafor, Ugochukwu, and Chijindu (2016), any rising company will have lower long-term earnings. Some claim that a rising company will try to keep up with the trend and therefore engage in earnings smoothing, which lowers the quality of reported results. Some may be motivated by a desire to meet a certain profit target. While some businesses that experience a decline in growth may prefer to report it as is because they are aware that manipulating earnings in order to portray good business health could spell doom for the company in the long run, especially if the company is not under any pressure to meet earnings targets. According to Sepasi et al. (2016), growth prospects give managers with an incentive to smooth earnings because earnings volatility increases perceived firm risk, which has a negative impact on the business's cost of capital. The research of Ongore et al. (2011) backs this up. According to the agency theory, agency costs are higher in highly developed businesses. This means that corporations must release more information to meet the needs of stakeholders in order to cut expenses.

\section{Firm's Profitability}

Profitable companies are more likely to share more evidence to show their superior performance. Sulong, et al. (2013) reported that when profits are strong, managers are more willing to reveal specific information to demonstrate their ability to maximize shareholder value, strengthen the security of their positions, and justify their pay. Managers of profitable businesses may also be proud of their achievements and give more information to the public in order to build a favourable image of their work (Uche et al., 2016). Unprofitable businesses, on the other hand, are less likely to give additional information in order to conceal their poor performance. Indrarini et al. (2019) used agency and signaling theories to propose that when managers have "positive news" attributable to greater performance, they 
provide more specific information to the market than when they have "bad news" to prevent their shares from being discounted.

\section{Review of Empirical Studies}

Several research has been carried out to investigate the linear and non-linear relationship between IO and FRQ. However, no consensus has been formed based on the findings of such investigations. Some studies have discovered a favorable relationship between IO and FRQ, whereas others have discovered a negative relationship. The impact of IO on FRQ is a point of contention (Okafor, Ugochukwu, \& Chijindu, 2016). Obviously, the efficiency of external monitoring by institutional investors may diminish the managers' tendency to control reported results. Institutional investors, on the other hand, may instruct management to make accounting decisions that favor short-term profits above long-term value (Gugong et al., 2014). Some institutional investors are "temporary owners" who are just interested in making a quick profit. Short-term institutional ownership encourages management to cut R\&D spending in order to increase profits (Yaghoobi \& Khansalar, 2016). Wahyu et al. (2016) use a sample of 121 US enterprises from 2002 to 2005 to study the impact of IO on FRQ. The findings imply that IO's active monitoring can help to prevent opportunistic financial reporting and improve the financial reporting process. Similarly, Ongore et al. (2011) find empirical evidence of a positive relationship between IO and FRQ. These findings are also in line with findings (Okafor, Ugochukwu, \& Chijindu, 2016). Sultana, Singh, and Van der Zahn (2015), on the other hand, use financial and stock price data from Malaysian enterprises from 2008 to 2009 to investigate IO and earnings quality (EQ) using three separate constructs: earnings predictability, earnings informativeness, and earnings persistence. Their data show that IO and FRQ have an inverse relationship. Yanida and Widyatama (2019) also find comparable results when it comes to the link between IO and FRQ. Strong shareholder rights lead managers to declare superior earnings quality, according to Yurisandi and Puspitasari (2015). When the majority of stocks are owned by short-term institutional investors, however, shareholders' efforts to decrease aggression and earn management were futile. Managerial ownership, according to Yusuf, Tambaya, and Badamasi (2016), can increase profits quality. Managerial ownership has a negative relationship with earnings management, resulting in higher FRQ and earnings quality (Sulong et al., 2013). As a result, board or management ownership is required to motivate managers' performance. It also encourages the board to devote more time to monitor the conduct of managers. As a result, managers will do their all to achieve higher-quality earnings. Adebiyi and Olowookere (2016) examine the impact of foreign investors on the informational efficiency of share prices in Japanese companies, concluding that an increase in foreign investors improves share price efficiency. International institutional investors in China diminish expropriation by controlling owners significantly, according to an emerging market study, because foreign investors are less associated with political worry and positively monitor invested enterprises. Following the lifting of Taiwan's foreign investor restrictions, international investors have contributed significantly to the country's capital market and have increased voluntary disclosure of Taiwanese companies. As a significant institutional investor, foreign investors appear to play an important monitoring role.

\section{Agency Theory}

Politics, economics, sociology, management, marketing, accounting, and administration are all examples of domains where agency theory has been applied. Any discussion of corporate governance usually begins with the agency theory. The concept of separation of ownership (principal) and management underpins the philosophy (agent). It states that when information asymmetry exists, the agent is more likely to pursue an interest that will harm the principal (Alqatamin, 2018). It is also focused on ensuring that agents work in the principals' best interests. Lakhal et al. (2015) define agency theory as a contract in which a 
principal engages an agent to perform some contractual obligation(s) authoritatively on their behalf in firms. The contract is intended to produce transparent, dependable, and correct financial accounting statistics in the financial report because the agreement is jointly expressed (Ongore et al., 2011). As a result, the agency theory remains the most prominent theory that accurately describes the concept of agency, and it has an impact on both public and private businesses (Yurisandi \& Puspitasari, 2015). Surprisingly, the agency theory allows for the examination of the firm's accountability in a hierarchical structure, even when direct cost control and monitoring are unfeasible.

For both owners and managers, a well-designed CG mechanism can reduce agency expenses. This is true because, by ensuring that agents are held accountable for their acts or inactions through monitoring, they will be forced to incur agency costs based on the risk of adverse selection, shirking, and moral hazards connected with the principals devaluing the company's worth (Yusuf et al., 2016). Because of the agency issues that arise from the separation of ownership and control in today's international corporate environment, effective CG is regarded to be important as an oversight tool for management control and aligning the principals' interests with the managers' interests.

\section{Research Design}

\section{METHODOLOGY}

This study adopts a multi-method quantitative model, which utilizes both descriptive and inferential statistics. The method is appropriate because it is inclined on the positivist research philosophy and deductive approach. The study examines the impact of some essential CG mechanisms on FRQ in Nigerian listed firms, which are measured numerically and analyzed using a range of statistical techniques (Yaghoobi \& Khansalar, 2016).

This study employed archival evidence, where quantitative data and CG information were obtained through secondary sources using 41 firms as the sample size of the study. The study covered non-financial companies in Nigeria within the period of nine years from 2011 to 2019. This period is particularly significant for this study because 2011 was the period when the World Bank re-evaluated the newly promulgated CG code, which took effect from April 2011 until 2018 where the SEC issued a revised CG code.

The study used two sets of data from the financial statements for all observations: the first is the data to measure the corporate governance variables while the second is the data to measure FRQ taking EM as its proxy. To analyze the samples, $\mathrm{CG}$ variables were obtained from financial statements for the years under study. The impact of corporate governance and FRQ was analyzed to examine the degree of relationship between the two sets of variables for the same time frame. The study used both descriptive and inferential statistics using STATA 16 for the analysis of the result.

\section{Earnings Management Model}

The existing models of DA have different explanatory power in different countries all over the world due to several factors such as institutional factors, CG mechanism, and legal system (Yaghoobi \& Khansalar, 2016). However, according to Gugong et al. (2014) the most reliable and consistent models to detect manipulative financial reports, using the manager's discretionary right of accounting methods choice and estimates are Jones (1991) model, modified Jones models by Dechow et al. (1995), and Kasznik (1999).

Further, the modified Jones model by Dechow et al. (1995) is considered as one the best and most powerful models for testing EM in Nigeria (Alsmady, 2018). The model recognizes accounting variations in income receivables in the event period. Therefore, managers revert to manipulating earnings on credit sales rather than cash sales. The modified Jones (1991) model allows credit sales variations during the 
period of the event as a result of EM (Bamahros \& Wan-Hussin, 2016). Thus, this is a present study that adopts and used the modified Jones (1991) Model (Dechow et al., 1995). The model is presented below :

TACit $=$ EBITit - CFOit $(1)$

Where :

TAC is total accruals, EBIT is earnings before interest and tax minus CFO, which is the cash flow from operations for specific firms' year and industry represented by ' $i$ ' for industry and ' $t$ ' for the year. The DA was calculated using the equation below:

$\frac{\text { TACit }}{\text { TAit }-1}=\alpha_{0}+\alpha_{1}\left(\frac{1}{\text { TAit }-1}\right)+\alpha_{2}\left[\frac{(\Delta \text { REVit }-\Delta \text { RECit })}{\text { TAit }-1}\right]+\alpha_{3}\left(\frac{\text { PPEit }}{\text { TAit }-1}\right)+\varepsilon i t$

Where :

TA is the previous year's total assets

$\triangle \mathrm{REV}$ is the change in revenue

$\triangle \mathrm{REC}$ is the change in trade receivables

PPE is property, plant, and equipment

$\mathcal{E}$ is the error term.

This present study followed Dechow et al. (1995) in terms of subtracting the change in accounts receivable from the change in revenue before the estimation. The aspects of the industry- and yearspecific will then be used for the parameter estimation of the coefficients. (a0, a1, a2, and a3), were calculated from equation (2), and after that, the non-discretionary accruals (NDAs) were found from the equation below:

$\mathrm{NDA}=\alpha_{0}+\alpha_{1}\left(\frac{1}{\text { TAit }-1}\right)+\alpha_{2}\left[\frac{(\Delta \text { REVit }-\Delta \text { RECit })}{\text { TAit }-1}\right]+\alpha_{3}\left(\frac{\text { PPEit }}{\text { TAit }-1}\right)+\varepsilon$ it

The total residuals of the DA are also found from the difference in the estimation of equation (3) and the actual accruals as depicted in the equation below:

DAit $=$ TACit - NDAit

Where:

NDA is non-discretionary accruals and DA is discretionary accruals. Consequently, the residual from the above model is used as a measure for EM in the equation below:

DAit $=f(\mathrm{IO} ;$ MGTOWN; FROWN $)$

In econometric form:

DAit $=\beta 0+\beta 1$ IOit $+\beta 2$ MGTOWNit $+\beta 3$ FROWNit $+\varepsilon$ it $\ldots(6)$

Adding control variables to the study, the model is represented as:

DAit $=\beta 0+\beta 1$ IOit $+\beta 2$ MGTOWNit $+\beta 3$ FROWNit $+\beta 10$ ROAit $+\beta 11$ FGRWit $+\varepsilon$ it 
Where :

FRQDA-it = Financial Reporting Quality as measured using Earnings Management (Discretionary Accruals);

$\beta 0=$ Constant;

IO = Institutional Ownership;

MGTOWN = Managerial Ownership;

FROWN = Foreign Ownership;

ROA $=$ Returns on Assets;

FGRW = Firm's Growth;

$\beta_{1} \ldots \beta_{13}=$ Coefficient of explanatory variables

$\varepsilon=$ Standard error

$\mathrm{i}=$ Cross sectional (Companies)

$\mathrm{t}=$ Time Series $(9$ years $)$

A priori expectations in line with extant literature to be $\beta 1, \beta 2, \beta 3 \ldots .>0$

\section{Descriptive Statistics of Continuous Variables}

\section{INTERPRETATIONS OF RESULTS}

Table 1 presents the result of the descriptive statistics of the continuous variables. It is described based on the minimum, maximum, standard deviation, and mean values.

Table 1. Descriptive Statistics of Continuous Variables

\begin{tabular}{|l|r|r|r|r|r|r|}
\hline Variable & Min & Max & Mean & Sd & Skewness & Kurtosis \\
\hline DA & 0.001 & 0.36 & 0.28 & 2.59 & 12.56 & 15.55 \\
\hline IO & 0 & 0.48 & 0.39 & 0.26 & -0.07 & 1.91 \\
\hline MGTOWN & 0.001 & 0.36 & 0.19 & 0.24 & 1.33 & 3.54 \\
\hline FROWN & 0 & 0.12 & 0.04 & 0.14 & 4.05 & 5.10 \\
\hline ROA & -0.19 & 0.23 & 0.14 & 0.11 & -3.04 & 7.73 \\
\hline FGRW & 7.73 & 12.33 & 9.97 & 0.86 & -0.07 & 2.95 \\
\hline
\end{tabular}

Source: Computed by the researcher using STATA 16

Table 1 shows the estimation of absolute value for Discretionary Accruals (DA) using the MJM (Dechow et al., 1995) and reported based on absolute values. The minimum value of DA is approximately 0.00025 and the maximum is 0.36 , while the mean value is 0.28 and the standard deviation is 2.59 . This means that the extent to which managers engage in opportunistic EM among listed firms on the NSE has reached up to $28 \%$ which is disturbing, and therefore, a cause for great concern. 
The mean value for institutional ownership (IO), managerial ownership (MGTOWN), and foreign ownership (FROWN) which are expressed as their proportion from the total equity capital are $0.39,0.19$, and 0.04 respectively. Similarly, their minimum values are $0,0.001$, and 0 while their maximum proportions are $0.48,0.36$, and 0.12 for each of the institutional ownership, managerial ownership, and foreign ownership respectively. Each of the three variables also has standard deviations of $0.26,0.24$, and 0.14 which discloses a departure from the mean as reasonable and normal. This shows that most firms have a sufficient proportion of institutional and managerial ownership but a very negligible proportion of foreign ownership in most firms. Furthermore, some firms do not have any of the three classes of investors in their equity capital as disclosed by a minimum value of virtually 0 for all the three classes of investors. Table 1 further reveals $48 \%$ as the maximum IO. The significant development of IOs' presence in most of the capital markets provides a basic background for corporate monitoring thereby, reducing EM and increasing FRQ among firms in Nigeria.

Looking at the mean of control variables measured as discrete data, the mean value of a firm's age is 27.21 while the minimum and maximum values are 10 and 54 respectively. The mean value for returns on assets is 0.14 while the minimum and maximum values are -0.19 and 0.23 respectively. This shows that while some firms incur a loss of up to $19 \%$ in their businesses, others generate a maximum of $23 \%$ returns on their assets. The average return on assets for the firms is $14 \%$. The standard deviation shows an $11 \%$ deviation from the mean. The deviation is fairly normal. The mean value for firms' growth is 9.97 while the minimum and maximum values are 7.73 and 12.33 respectively. This shows that the average revenue of Nigerian firms is being increased by $9.97 \%$. The standard deviation, as can be seen, shows an 8.6\% disparity from the mean. The variation is fairly normal (Saifullah et al., 2015). In addition, firm size (FSZE) has a minimum value of N19.13 billion, while the maximum value is N27.70 billion. Firm size indicates that on average, a Nigerian listed firm has assets worth N23.31 billion. The standard deviation shows N1.92 billion which is a normal disparity as it is not far from the mean. Looking at the skewness and kurtosis value, it can be observed that the data is moderately normal. The data set did not violet the normality assumption of the parametric data test. Similarly, Sulong et al. (2013) noted that even if the population is not normally distributed, but the sample size is large enough i.e $>30$, then the means will have an approximately normal distribution.

\section{Correlation Analysis}

This study regards correlation analysis as an essential procedure to examine whether or not a correlation subsists among variables. It is believed that zero relationships indicate the non-existence of connection between variables, and therefore, there is no need for conducting research with such unrelated variables (Wahyu et al., 2016). Therefore, there must be either a positive or negative connection between the dependent variable and all the explanatory variables for research to be conducted. In view of this, the correlation was performed to determine the link between DA and FRQ and explanatory variables. The correlation results for DA are presented in table 2 below.

Table 2. Correlation Matrix

\begin{tabular}{|l|l|l|l|l|l|l|}
\hline & DA & IO & MGTOWN & FROWNN & ROA & FGRWTH \\
\hline DA & 1.00 & & & & & \\
\hline IO & -0.03 & 1.00 & & & & \\
\hline MGTOWN & -0.04 & $-0.23^{* * *}$ & 1.00 & & & \\
\hline FROWNN & -0.02 & 0.08 & $-0.15^{* *}$ & 1.00 & & \\
\hline ROA & 0.01 & -0.01 & -0.07 & $0.11 * * *$ & 1.00 & \\
\hline
\end{tabular}




\begin{tabular}{|c|c|c|c|c|c|c|}
\hline FGRWTH & $0.14 * *$ & 0.08 & $-0.25 * * *$ & $0.11 * *$ & $\begin{array}{l}0.11 * * \\
*\end{array}$ & 1.00 \\
\hline
\end{tabular}

Source: Computed by the Researcher using STATA 16

Note: $* * *, * *$ and $*$ represent significant level at $1 \%, 5 \%$ and $10 \%$ respectively.

The results of the correlation analysis as shown in table 3 are mixed with some variables showing positive coefficients while others show negative coefficients. The coefficients with significant positive values are FGRW and DA (0.14); FROWN and ROA (0.11); FGRWTH and FROWN (0.11); FGRWTH and ROA (0.11). On the other hand, the coefficients with significant negative values are MGTO and IO (-0.23); FROWN and MGTO (-0.15); FGRW and MGTO (-0.25).

Having observed a non-zero correlation link between FRQ and all the explanatory variables as asserted by Bricker and Markarian (2015), analysis was carried out on FRQ and all the explanatory variables. Even though the correlation between FRQ and each of the independent variables seems to be weak as the value of the coefficients falls within the limit of $(r)<0.3$. Therefore, multicollinearity does not exist in the correlation.

\section{RESULTS AND DISCUSSIONS}

The results for Dynamic Panel Results for Discretionary Accruals Model is shown in table 3

Table 3. Discretionary Accruals Results using Dechow et al. (1995): Two-Step System GMM

\begin{tabular}{|l|l|l|l|l|}
\hline Variables & Coefficient & Std. Err. & z-statistics & $\boldsymbol{p}$-Value \\
\hline DA L1 & $0.3247^{* * *}$ & 0.0049 & 66.67 & 0.000 \\
\hline IO & $-0.6707^{* * *}$ & 0.2411 & -2.78 & 0.005 \\
\hline MGTOWN & -0.0728 & 0.2780 & -0.26 & 0.793 \\
\hline FROWN & $-1.1447^{*}$ & 0.6930 & 1.65 & 0.099 \\
\hline FGRW & $-0.4522^{* * *}$ & 0.0783 & -5.78 & 0.000 \\
\hline ROA & $0.8059^{* * *}$ & 0.0195 & 41.28 & 0.000 \\
\hline cons & $8.7086^{* * *}$ & 0.8083 & 10.77 & 0.000 \\
\hline Statistics & Coefficient & & & $\boldsymbol{p}$-Value \\
\hline Wald chi2(12) & 331727.37 & & & \\
\hline Prob > chi2 & & & & 0.000 \\
\hline AR2 & & & & 0.486 \\
\hline Hansen J. & & & & 0.376 \\
\hline No. of Group & 41 & & & \\
\hline No. of Instrument & 35 & & & \\
\hline
\end{tabular}

Source: Computed by the researcher using STATA 16

Notes: $* * * \mathrm{p}<0.01, * * \mathrm{p}<0.05, * \mathrm{p}<0.1$, indicate significance levels

The results show that the lagged dependent variable is significant at a $1 \%$ level of significance with lag one of three $\left(\begin{array}{ll}1 & 2\end{array}\right)$ and the coefficient value is 0.3247 , using the second lag. The use of second lags became necessary as it is not correlated with the current error term. However, the first lag is correlated. It is also used to find suitable instruments for model efficiency. Thus, the results indicate that the lag argument is correctly specified and the instruments used are valid. 
The result indicates that IO has a significant negative association with a $p$-value $=0.005$, while the coefficient is -0.6707 . It shows that the inclusion of a shareholder with financial expertise in the AC can decrease EM by -0.6707 , on the econometric assumption that other factors remain constant. Therefore, the result gives enough evidence to reject the hypothesis which argues that IO has no significant impact on EM practice in listed firms in Nigeria. Therefore, hypothesis H1 is not supported.

The result is in line with the argument that IO, as owners, activists, and powerful shareholders can check opportunistic managerial behaviour and improve good CG. This study is consistent with that of Dou et al. (2018) that have examined the IO role in improving the FRQ.

The result also reveals that MGTOWN has an insignificant negative relationship with $\mathrm{p}$-value = 0.793, while the coefficient value is -0.0728 . It means that a company with MGTOWN could lower the extent of EM by a parameter value of -0.0728 , on the econometric assumption that all other factors remain constant. However, looking at its insignificant p-value, the result provides sufficient evidence to support the hypothesis which states that there is no significant relationship between managerial ownership and EM practice by listed firms in Nigeria. Hypothesis 2 is, therefore, supported.

The result also shows that FROWN has a significantly positive relationship with EM with a coefficient of -1.1447 and a p-value of 0.099. This implies that the presence of FROWN decreases the extent of EM by a parameter value of -1.1447 on the econometric assumption that all other factors remain constant. Consequently, there is enough evidence to support the existence of a significant negative relationship between FROWN and EM, the result also supports the established theoretical assumption of both the agency and resource dependence theories. Therefore, hypothesis 3 is not supported.

Consequently, FROWN can provide the needed monitoring and suppress EM practice in firms listed on the NSE. The result is also consistent with the study of Saifullah et al. (2015) indicating that foreign investors bring stakeholders' confidence, increase invention and lead to high demand for a qualitative financial report.

This result is not consistent with Elyasiani et al. (2017) who argued that foreign investors in Nigerian firms are protecting their interests and are benefit-seekers rather than providing monitoring activities, hence compromising their status by aligning to the management's needs. Their connivance with managers in earnings smoothing is used to display a script-like performance in the AGM in favour of the manager's financial report (Ongore et al., 2011). However, these features are mostly found in transient investors, unlike dedicated investors that are not likely to connive with the managers to defraud the firm (Alsmady, 2018).

The regression results of the dynamic panel (GMM) show a statistically significant relationship between DA and ROA as a control variable the $\mathrm{p}$-value $=0.000$ while the coefficient value is 0.8059 .

The result for FGRW also indicates a negative relationship with EM and the p-value $=0.000$ while the coefficient value is -0.4522 . This result provides sufficient evidence to support that firms having a higher percentage of growth may wish to publish their financial report as early as possible to immediately release their audited corporate annual statements and to convey the favourable report as advocated in the previous studies (Affan et al., 2017).

\section{CONCLUSION AND RECOMMENDATIONS}

This study like most of the previous ones has documented that IO can restrain the extent of EM in Nigeria. It is believed that the greater the level of IO, the more likely it is that a company will provide audits that are carried out by a recognized audit firm. This result is also consistent with both the resource dependency and agency theories in terms of conflict resolutions and effective resources usage (Arowolo \& CheAhmad, 2017). Therefore, IO in Nigeria put more pressure on managers to provide more quality financial reports. 
Similarly, foreign ownership is also found to be effective in reducing EM through their zeal and agitation to ensure firms comply with the international financial reporting practice. This enables the management to run the company in the interests of shareholders rather than personal interests in order to achieve worldwide recognition. In addition, foreign ownership also induces the management to be more open in disclosing all information relating to both financial and non-financial in order to convince investors that the company is in good condition so that the company will increase its value globally.

However, managerial ownership managers are less subjected to accounting-based restraints. therefore, managers can decrease the quality of information disclosure as a result of proprietary costs of disclosure, since the fewer managers disclose, the fewer competitors and suppliers know about the firm's financial position. Yaghoobi and Khansalar (2016) find that the information effect, where there are greater incentives to disclose as little proprietary information to the public as possible, is significant for firms with concentrated ownership.

Firms should, therefore, expand their institutional and foreign ownership by providing sufficient shares to them. This is important because they frequently deploy their professionalism and wealth of experience to the firms towards meeting corporate goals and agitation of good reporting practice. On the other hand, Firms should ensure that shareholding of the insider managers is not too high in such a way that the proportion of their shareholding should be minimal which should not exceed $10 \%$ of the total shareholding in the company as it was found being among the factors that reduce firms performance.

\section{AUTHOR CONTRIBUTIONS}

Conceptualization: K. M. Anwarul Islam, Junaidu Muhammad Kurawa, Ismail Alhassan

Data Curation: K. M. Anwarul Islam, Junaidu Muhammad Kurawa, Ismail Alhassan

Formal Analysis: K. M. Anwarul Islam, Junaidu Muhammad Kurawa, Ismail Alhassan

Funding Acquisition: K. M. Anwarul Islam, Md. Shariful Haque

Investigation: K. M. Anwarul Islam, Junaidu Muhammad Kurawa, Ismail Alhassan

Methodology: K. M. Anwarul Islam, Junaidu Muhammad Kurawa, Ismail Alhassan

Project Administration: K. M. Anwarul Islam

Resources: K. M. Anwarul Islam

Software: K. M. Anwarul Islam, Junaidu Muhammad Kurawa, Ismail Alhassan

Supervision: K. M. Anwarul Islam

Validation: K. M. Anwarul Islam, Junaidu Muhammad Kurawa, Ismail Alhassan, Md. Shariful Haque

Visualization: K. M. Anwarul Islam

Writing - Original Draft: K. M. Anwarul Islam, Junaidu Muhammad Kurawa, Ismail Alhassan

Writing - Review \& Editing: K. M. Anwarul Islam, Md. Shariful Haque

\section{CONFLICT OF INTEREST STATEMENT}

The authors declare that they have no competing interests.

\section{ACKNOWLEDGEMENT}

All authors contributed equally to the conception and design of the study.

\section{REFERENCES}

Adebiyi, W. K., \& Olowookere, J. K. (2016). Ownership Structure and the Quality of Financial Reporting: Evidence from Nigerian Deposit Money Banks. International Journal of Economics, Commerce and Management, 4(1), 541-552. 
Amin, A. S., Dutta, S., Saadi, S., \& Vora, P. P. (2015). Institutional Shareholding and Information Content of Dividend Surprises: Re-Examining the Dynamics in Dividend-Reappearance Era. Journal of Corporate Finance, 31, 152-170.

Alqatamin, R. M. (2018). Audit committee effectiveness and company performance: Evidence from Jordan. Accounting and Finance Research, 7(2), 48.

Affan, W. M., Rosidi, S. E., \& Purwanti, L. (2017). The Effect of Ownership Structure on the Quality of Financial Reporting of Manufacturing Companies Listed in the IDX. Imperial Journal of Interdisciplinary Research 3(7), $34-46$.

Al-Jaifi, H. A., Al-Rassas, A. H., \& Al-Qadasi, A. (2019). Institutional Investor Preferences: Do Internal Auditing Function and Audit Committee Effectiveness Matter in Malaysia? Management Research Review, 22(1), 108-122.

Alsmady, A. A. (2018). Ownership Structure and its Endogeneity Effect on the Quality of Financial Reporting. International Journal of Academic Research in Business and Social Sciences, 8(3), 509-526.

Arowolo, R. O., \& Che-Ahmad, A. (2017). Block-holders and Monitoring Mechanisms in Nigeria. Asian Journal of Accounting and Governance, 78(8), 71-78.

Bricker, R., \& Markarian, G. (2015). Institutional investors and insider trading profitability. European Accounting Review, 24(3), 495-518.

Bamahros, H. M., \& Wan-Hussin, W. N. (2015). Types of Institutional Investors and Earnings Management in Malaysia. Advanced Science Letters, 21(6), 2003-2006.

Bamahros, H. M., \& Wan-Hussin, W. N. (2016). Types of Institutional Investors and Financial Reporting Timeliness: Empirical Study in Malaysia. International Conference on Accounting Studies, (August), 207-211.

Brooks, C., Chen, Z., \& Zeng, Y. (2018). Institutional cross-ownership and corporate strategy: The case of mergers and acquisitions. Journal of Corporate Finance, 48, 187-216.

Dou, Y., Hope, O.K., Thomas, W. B., \& Zou, Y. (2018). Blockholder Exit Threats and Financial Reporting Quality. Contemporary Accounting Research, 35(2), 1004-1028.

Dechow, P. M., Sloan, R. G., \& Sweeney, A. P. (1995). Detecting earnings management. Accounting Review, 70(2), 193-225.

Elyasiani, E., Wen, Y., \& Zhang, R. (2017). Institutional Ownership and Earning Management by Bank Holding Companies. Journal of Financial Research, 40(2), 147-178.

Gugong, B. K., Arugu, L. O., \& Dandago, K. I. (2014). The Impact of Ownership Structure on the Financial Performance of Listed Insurance Firms in Nigeria. International Journal of Academic Research in Accounting, Finance and Management Sciences, 4(1), 409-416. 
Indrarini, S., Chandrarin, G., \& Subiyantoro, G. (2019). Managerial Ownership, Earnings Predictability and Firm Value on Indonesia Stock Exchange. Journal of Business and Management, 11(2), 3946.

Jones, J. J. (1991). Earnings management during import relief investigations. Journal of accounting research, 29(2), 193-228.

Khafid, M., \& Arief, S. (2017). Managerial ownership, corporate governance and earnings quality: The role of institutional ownership as moderating variable. Pertanika Journal of Social Sciences and Humanities, 25, 241-254.

Kim, K. (2010). Blockholder Monitoring and the Efficiency of Pay-Performance Benchmarking. Journal of Corporate Finance, 16(5), 748-766.

Kasznik, R. (1999). On the association between voluntary disclosure and earnings management. Journal of accounting research, 37(1), 57-81.

Lakhal, F., Aguir, A., Lakhal, N., \& Malek, A. (2015). Do women on boards and in top management reduce earnings management? Evidence in France. Journal of Applied Business Research (JABR), 31(3), 1107-1118.

Mamman, S., Kurfi, B. U., Audi, A. M., Amos, B., \& Ahmad, A. A. (2016). Institutional Ownership and Earnings Quality: Evidence from Quoted Food / Beverages and Tobacco Firms in Nigeria. Nigerian Journal of Management Technology \& Development, 7(1) 87-101.

Ongore, V. O., K’Obonyo, P. O., Ogutu, G. (2011). Implications of Firm Ownership Identity and Managerial Discretion on Financial Performance: Empirical Evidence from Nairobi Stock Exchange. International Journal of Humanities and Social Science, 1(13), 187- 195.

Okafor, I. G., Ugochukwu, U. S., \& Chijindu, E. H. (2016). Foreign capital inflows and Nigerian economic growth nexus: A Toda Yamamoto approach. European Journal of Accounting, Auditing and Finance Research, 4(3), 16-26.

Saifullah, M. A., Mohammed, A., \& Usman, S. H. (2015). Ownership Diversity and Corporate Performance: Evidence from Nigerian Conglomerates Firms. Journal of Basic and Applied Research, 1(1), 89-101.

Sepasi, S., Kazempour, M., \& Mansourlakoraj, R. (2016). Ownership Structure and Disclosure Quality: Case of Iran. 1st International Conference on Applied Economics and Business, Procedia Economics and Finance, 36(16), 108 - 112.

Sulong, Z., John, C., Gardner, A.H.H., Zuraidah, M.S., \& Carl, B.M. (2013). Managerial Ownership, Leverage and Audit Quality Impact on Firm Performance: Evidence from the Malaysian Ace Market. Accounting \& Taxation Journal, 5(1), 59-70.

Sultana, N., Singh, H., \& Van der Zahn, J. L. M. (2015). Audit committee characteristics and audit report lag. International Journal of Auditing, 19(2), 72-87. 
Uche, C. O., Adegbite, E., \& Jones, M. (2016). Institutional shareholder activism in Nigeria: An accountability perspective. Accounting Forum, 40(2), 78-88.

Wahyu, A.A., Budiyanto, S. N., \& Nur, F. A. (2016). Ownership Structure in the Effect of Diversification Strategy on Capital Structure and Financial Performance of Companies Listed in Indonesia Stock Exchange, International Journal of Economics, Commerce and Management, 6(7), 344-371.

Yaghoobi, A., \& Khansalar, E. (2016). Review of the Relationship between Ownership Structure and Economic Performance Criteria in Companies Listed on Tehran Stock Exchange. International Journal of Economics and Finance, 8(6), 89-99.

Yanida, M., \& Widyatama, A. (2019). Does Corporate Governance Increase Financial Reporting Quality? Journal of Business: Theory and Practice, 3(5), 16-30.

Yurisandi, T., \& Puspitasari, E. (2015). Financial Reporting Quality-Before and After IFRS Adoption Using Nice Qualitative Characteristics Measurement. Procedia-Social Behavioral Sciences, 21(1), 644-652.

Yusuf, I., Tambaya, U. Y., \& Badamasi, M. (2016). Corporate Governance and Performance of Listed Deposit Money Banks in Nigeria. Institutional Frameworks, Building and National Development (IFBND) Conference 2016, 278 - 288.

\section{Copyrights}

Copyright for this article is retained by the author(s), with first publication rights granted to the journal. This is an open-access article distributed under the terms and conditions of the Creative Commons Attribution license (https://creativecommons.org/licenses/by/4.0). 